UDC 622.1:622.83+622.35

DOI: https://doi.org/10.26642/tn-2017-2(80)-173-180

V.G. Levytskyi, PhD

O.M. Tolkach, PhD

Zhytomyr State Technological University

\title{
Research of environmentally-friendly utilization methods of the crushed stone waste on granite quarries
}

The analysis of activity of stone-mining enterprises shows the low competitiveness of crushed stone products Upgrading the quality of crushed stone and production of the European standard fractions requires to use of new technologies and equipment. The main waste of crushed stone pits is crushed granite waste, which high percent of an exit is caused by outdated equipment and incorrectly selected technological parameters of the crushing process. Crushed-granite waste is stored in dumps which occupy large areas and negatively effect on production area ecology. In November 2017, the Government of Ukraine accepted the National Waste Management Strategy until 2030, the main aim of it is develop a strategy of the mineral raw materials balanced use and international standards introduction at the national level. Therefore, the problem of complex utilization and recycling of waste from stone-mining enterprises with receiving a qualitative secondary product is relevant.

The publication presents the crushed granite waste volumes by crushed stone pit, its properties and main directions of utilization. The ecological influence of waste dumps, in particular granite dust, on the environment and human, the strategy of using non-waste technologies and ecological features of crushed granite waste secondary processing are considered.

Keywords: crushed granite waste; crushed stone quarries; stone dust; waste recycling; granite waste.

Introduction and formulation of the problem. Intensification of the processes of mining and mineral processing is typical for the modern development of mining industry. But it is associated with the accumulation of significant amounts of waste and pollution of the environment. Therefore, comprehensive using of mineral resources is relevant today.

Today about 1.5 billion tons of rock mass are mined per year in Ukraine, but due to the peculiarities of the processes of mining and processing, the only 45-50\% of the total amount are used as aggregate (crushed stone), and other products in the form of mining waste are placed in a mining dumps. The total area of land affected by the open pit mining exceeds 500 thousand hectares, including about 400 thousand hectares occupied by mining dumps

One of the ways to solve the problem of waste utilization is to develop the technological solutions which will ensure the reuse of industrial waste for producing the products for various purposes. In this way, together with the raw material problem it could be possible to solve the environmental problems, which positively affects the surrounding nature and the geological environment. The problem of waste using is an environmental problem of regional scale, and the production of construction materials from industrial waste is one of the most promising methods for its solution.

The widespread use of the crushed stone waste is hampered by the lack of information on their composition and properties, as well as their impact on the structure and performance properties of building materials.

The aims of the article are to investigate the impact of the crushed stone waste on the ecological state of the environment, to analyze the features of waste utilization and the possibility of using them as fillers for concrete, silicate products and other products.

The analysis of researches and publications. The problems of the ecological management and the ecological policy relating waste policy were considered by E.R. Hubanova [1], I.V. Davydovs [2], V.V. Korobiichuk [3] and others.

Investigations of dust formation process and dust control methods on the rocks dumps were engaged V.K. Bagazeev, N.G. Valiev [4], A.E. Lapshin [5], V.I. Prokopenko [6], I.V. Sinitsa, E.V. Lyichagin [7], Yu.N. Malyishev [8].

Utilization of granite waste in the ceramic tiles manufacture was describes by C.M.F. Vieira [9], M. Hojamberdiev [10]. Dust formation and use of rocks dust at industrial sites investigate by S.Ya. Davydov [11]. the production of cement-based building elements incorporating high amounts of quarry dust was investigated in laboratory scale by [12]. Stone slurry is capable of improving hardened concrete performance up to $16 \%$, enhancing fresh concrete behaviour and can be used in architectural concrete mixtures [13].

Results of geopolymer binder research based on the grinded waste from production and processing of magmatic rocks (dust crushing of the granite) with the addition of slag describes by N.Eroshkina [14], L.N. Tchadjié [15]. Geopolymer binder has, in comparison with the classical, larger resistance to corrosion, 
smaller time of hardening. The final hardening takes place in a week, while for classic concrete this term is a month. The advantage in comparison with portland cement is a higher level of coupling with any surface. Also, this material has high degree of resistance to bending and stretching, resistance to acidic influence and temperature changes.

Presentation of the major research material.

1. Characteristics of the crushed stone waste.

A large number of crushed stone quarries are located on the territory of Zhytomyr region. This is due to the fact that the Zhytomyr region is located on the most ancient geological structure in Ukraine - the Ukrainian crystalline shield. Most of the deposits of the Ukrainian shield are located in the Zhytomyr region (Fig. 1). Different types of rocks are mined and processed at these plants, such as: granite, quartzite, migmatites, gabbro, labradorite, anorthosite, sandstone. Most of the above-mentioned rocks are used for the production of crushed stone.

The most common crystalline rock in the region presented above is granite. This is primarily due to favorable geological conditions - most granites of the Zhytomyr region are close to the daytime surface. Thus, granites are mined in such deposits as Lesznikivsky, Berezivsky, Davydivsky, Korostensky, Bekhivskyi, Raykivsky and other deposits in order to obtain a building stone.



Figure 1. Mineral resources of Zhytomyr region

Granites refer to Korosten, Kirovograd-Zhytomyr, Chudniv-Berdichiv and Buky complexes and differ in their chemical composition, physical-mechanical and technological properties. Analysis of data on the abovementioned deposits shows that the crystalline rocks of the Zhytomyr region are massive strong natural aggregates that are suitable for the production of the facing stone and crushed stone. Aggregates made from such a hard rocks of Zhytomyr region (granite, quartzite, gabbro, sandstone) has a high quality, which determines its popularity. At the processing of crushed stone a significant amount of waste is formed (up to $40 \%$ ), which is considered a waste and has no further massive use in the quarries. The chemical composition of the crushed stone waste is presented in Table 1.

The chemical composition of the crushed stone waste

Table 1

\begin{tabular}{|c|c|c|c|c|c|c|c|c|c|c|}
\hline Deposit & Rock & $\mathbf{S i O}_{2}$ & $\mathbf{A l}_{2} \mathbf{O}_{3}$ & $\mathbf{F e}_{2} \mathbf{O}_{3}$ & $\mathbf{F e O}$ & $\mathbf{C a O}$ & $\mathbf{M g O}$ & $\mathbf{K}_{2} \mathrm{O}$ & $\mathbf{N a}_{2} \mathrm{O}$ & $\mathbf{T i O}_{2}$ \\
\hline Bekhivskyi & granodiorite & 58,70 & 14,55 & 2,56 & 5,83 & 4,70 & 2,30 & 3,20 & 4,00 & 1,81 \\
\hline Bilokorovitsky & sandstone & 84,90 & 8,00 & 0,58 & 0,36 & 0,24 & 0,40 & 2,24 & 0,72 & 0,31 \\
\hline Korostensky & granite & 71,20 & 14,20 & 0,38 & 2,10 & 1,68 & 0,56 & 4,64 & 3,20 & 0,45 \\
\hline
\end{tabular}

The main properties and the composition of crushed stone waste and their derivatives are almost identical, therefore the use of waste as a road material is allowed without restrictions. According to the grain composition the crushed stone waste can be attributed to the large-, medium-, and fine-grained materials with different size modulus (Table 2). But it doesn't use as aggregate of concrete and building sand in the natural state, because it is not homogeneous formations. 
Granulometric composition of the crushed stone waste on the Zhytomyr region quarries

\begin{tabular}{|c|l|l|l|l|l|l|l|c|c|}
\hline \multirow{2}{*}{ Deposit } & \multicolumn{7}{|c|}{ Granulometric composition (\%) for fractions, mm } & \multirow{2}{*}{$\begin{array}{c}\text { Sizing } \\
\text { module }\end{array}$} & $\begin{array}{c}\text { The number } \\
\text { of clay and } \\
\text { dust particles }\end{array}$ \\
\cline { 2 - 11 } & $>5$ & $5-2,5$ & $\begin{array}{l}2,5- \\
1,25\end{array}$ & $\begin{array}{l}1,25- \\
0,63\end{array}$ & $\begin{array}{l}0,63- \\
0,315\end{array}$ & $\begin{array}{l}0,315- \\
0,16\end{array}$ & $<0,16$ & 3,1 & 11,22 \\
\hline Berezivsky & 14,40 & 12,30 & 28,86 & 11,84 & 8,54 & 6,18 & 17,88 & 3,0 & 9,08 \\
\hline Bekhivsky-I & 9,01 & 19,13 & 19,60 & 16,12 & 10,20 & 7,50 & 18,44 & 3,0 & 12,46 \\
\hline Bekhivsky -II & 19,02 & 15,08 & 16,40 & 11,30 & 9,64 & 7,04 & 21,52 & 3,0 & 9,78 \\
\hline Omelyanovsky & 7,8 & 15,84 & 20,80 & 16,74 & 11,36 & 8,20 & 19,26 & 2,8 & 10,58 \\
\hline Korostensky & - & 20,70 & 22,40 & 19,40 & 11,60 & 7,68 & 18,22 & 2,8 & 13,88 \\
\hline Luginsky & 4,38 & 11,18 & 17,74 & 15,82 & 17,00 & 11,94 & 26,32 & 2,2 & 7,26 \\
\hline Penizevitsky & 10,10 & 32,64 & 24,10 & 12,30 & 4,28 & 4,20 & 12,48 & 3,6 & 9,00 \\
\hline Tovkachvsky & 19,02 & 20,66 & 20,40 & 13,60 & 6,34 & 5,42 & 14,56 & 3,4 & 10,86 \\
\hline Ushitsky & 9,80 & 10,04 & 22,94 & 14,04 & 10,64 & 9,24 & 23,30 & 2,6 & \\
\hline
\end{tabular}

\section{The impact of granite quarries waste on the environment}

Mining-industrial waste, in particular granite droppings, is a source of secondary pollution of the air basin and open water reservoirs by dust. It is known that man-made arrays are characterized by large areas and a damaged surface. Under the influence of atmospheric conditions (wind speed, humidity) there are processes of dust forming on the surface, which contribute to the spread of dust over long distances. In fact, from 1 hectare of mining dumps dry surface about 2 tons of fine dust can be transported by wind per day. According to the previous research it was found, that when the dust is transported by wind more than $58 \mathrm{~kg}$ per month on the area of 1 hectare, the effect of vital activity deterioration of most plants and animals of this region is observed.

The use of traditional methods for assessing the impact on one or another component of the environment does not allow obtaining a coherent picture of the technological burden on these components. In particular, a comprehensive account of aggressive pollutants entering the environment is not made, and the integrated estimates of the impact on natural resources for their consumption are not listed anywhere. Estimates do not take into account the emissions of non-toxic substances, although their presence in the atmosphere also changes the quality of the air, contaminating it. Also, estimates do not take into account the differences in substances in their toxicity and duration of exposure to the atmosphere. As a result of the mixing with atmosphere of harmful substances of the same mass, but different toxicity, the result of the effect may vary. It is also important to take into account the period of time during which the pollutants are stored in the natural environment. In particular, in the atmosphere it varies from many years to several hours. Therefore, it is necessary to make an integrated assessment taking into account all of these factors.

This evaluation is performed using the integral index $Z^{\tau}$, which representing the sum of relative deviations of the resource amount actual values from its initial (natural) values [4,5]. The load on the atmosphere can be calculated by the formula:

$$
Z^{\tau}=\frac{\sum_{t=1}^{\tau}\left|V_{i}\right|}{\sum_{t=1}^{\tau} R_{t}}+\frac{\sum_{t=1}^{\tau}\left|G_{i}\right| \cdot K_{H}}{\sum_{t=1}^{\tau} R_{t}},
$$

where $V_{i}$ is the value of resource stocks deviation as a result of the atmospheres resource (air) consumption; $G_{i}$ is the value of part of resource that has changed its properties as a result of the entering into the resource of foreign matter; $K_{H}$ is the load factor; $R_{t}$ is a reserves of resources; $t$ - is the evaluation temporary intervals; $\tau-$ is the upper bound of the temporary assessment.

The load factor shows the degree of consumption of the resource as a result of changes in its natural properties when contributing foreign matter and can be determined as:

$$
K_{H}=A_{i} \cdot T_{i},
$$

where $A_{i}-$ is the the ratio of the marginal value of the indicator for the sanitary assessment of the environment of the safest substance to the value of this indicator of the $\mathrm{i}$-th substance; $T_{i}$ is the correction for the time of the presence of impurities in the environment:

$$
T_{i}=\frac{t_{i}}{t_{o}}
$$

where $t_{i}$ is the duration of the selected time interval of evaluation; $t_{o}$ is the duration of impurity existence. In the case where the duration of the impurity existence exceeds the duration of the time interval $t_{i}$, it is assumed to be equal to $t_{o}$. 
The results of the evaluation of the methodology presented above are indicated that the main component which influence on the atmosphere is dust.

Mineral dust acts negatively on human respiratory organs. The most dangerous for the human body is dust particles up to 10 microns, containing free crystalline silica in its modifications. It is known that degree of harmfulness of dust to quarry workers is determined by its physical and chemical properties and concentration in the air. In turn, the properties of dust particles depend on their mineral and chemical composition and size.

The disperse composition of dust can be represented as content by quantity or by weight of particles of different fractions. Most of industrial dust is subject to the normal-logarithmic distribution of particle size. In this case, the integral particle size distribution curve has the following form as [11]:

$$
D\left(d_{u}\right)=\frac{100}{\lg \sigma_{u} \sqrt{2 \pi}} \int_{-\infty}^{\lg d_{u}} e^{\frac{\lg ^{2}\left(d_{u} / d_{M}\right)}{2 \lg ^{2} \sigma_{u}}} d \lg d_{\psi},
$$

where $D\left(d_{u}\right)$ is the relative content of particles less than this size $d_{u}, \% ; \sigma_{u}$ is the mean square deviation in the function of this distribution; $\lg \left(d_{u} / d_{M}\right)$ is the logarithm of the ratio of the current size $d_{u}$ to the median for a given size distribution $d_{M}$, which is the size in which the number of particles bigger than $d_{M}$ is equal to the number of particles smaller than $d_{M}$.

A detailed description of the change in the dust properties, depending on the size of particles, is given in Table 3. The data of investigation for granulometric composition of granite crushed stone waste are presented in Table 2.

The main ways to combat atmospheric pollution are humidifying the dumps or processing them with different astringent substances (resins, organic polymers, bituminous emulsions, cements), which form the protective films on the surface of the mining dumps. However, the effect of these measures is temporary and local. One of the measures is also biological reclamation. Obviously, the cardinal solution of the problem can be to reduce and maximize use of all crushed stone waste of the quarries.

The analysis of the granulometric composition of granite waste is shown that one of the main components is dust, which is about $20 \%$. Therefore possible the next ways to use dust such as [11]:

- target products;

- return to production, in the technology of which this type of dust is formed;

- recycling of dust in another manufacturing with obtaining commodity products;

- utilization for construction purposes;

- agricultural using, etc.

Table 3

Properties of dust depending on the size of the particles

\begin{tabular}{|c|c|c|c|c|}
\hline \multirow{2}{*}{ Indicator } & \multicolumn{4}{|c|}{ Particle size, $\mu \mathrm{m}$} \\
\hline & $>5$ & $0,1-5$ & $0,001-0,1$ & $<0,001$ \\
\hline $\begin{array}{c}\text { Characteristics of } \\
\text { particles }\end{array}$ & coarse-grained & finely divided & colloidal & molecular \\
\hline $\begin{array}{l}\text { Visibility in } \\
\text { observation }\end{array}$ & visible to the eye & $\begin{array}{l}\text { visible under a } \\
\text { microscope }\end{array}$ & $\begin{array}{c}\text { visible under } \\
\text { ultramicroscope }\end{array}$ & invisible \\
\hline Ability to diffuse & not capable & almost unable to & $\begin{array}{c}\text { capable of low } \\
\text { speed }\end{array}$ & capable of \\
\hline $\begin{array}{l}\text { Ability to } \\
\text { coagulate }\end{array}$ & not capable & capable & capable & not capable \\
\hline $\begin{array}{c}\text { Participation in } \\
\text { the Brownian } \\
\text { movement }\end{array}$ & do not take part & small participation & take part & take part \\
\hline
\end{tabular}

The dust generated during the mining and mineral processing is used in the construction industry and for road construction in the production of materials such as bricks and tiles. The studies of the possibility of using a quarry dust on cement mixtures are focused on the partial replacement of sand. At that the size of the dust particles is important, since the deviation from the admissible particle size, can significantly change the properties of cement mixtures in a bad way. For dust of magmatic rocks the average diameter of particles is 20-30 microns, area of the specific surface is $2500-4500 \mathrm{~cm}^{2} / \mathrm{cm}^{3}$.

3. Non-waste and low-waste technologies use.

The analysis of technological processes carried out at the industrial enterprises of the Zhytomyr region shows that in a number of industrial production has achieved a low-waste and even non-waste technology for the 
minerals processing, at other enterprises achievement of low-waste technology is possible, but some production form such waste, which cannot be processed into useful product now and are subject to burial.

Practically, low-waste and even non-waste technologies should include processes of building stone processing into a bunch-crushed products, facing stones - in decorative-facing products.

The crushed stone waste is immediately directed to the road organizations for filling, repairing, and arranging highways [16]. Very often and in the considerable volumes, these wastes are applied for filling up the intra-carriage and pre-carriageways, which are intensively destroyed by heavy transport and become inoperable, especially during the winter.

Crushed-granite waste of Zhytomyr region crushed stone pits and factories is used for the manufacture of concrete wall stones. The crushed granite waste serves as a filler of these stones. The granite dropout expense for 1 thousand pieces the conditional brick wall stones is $1,73 \mathrm{~m}^{3}$. Using the crushed granite waste in 2009 allowed to receive 39,6 million pcs. conditional brick-wall stones on a granite filler. The plan for 2010 provided for the manufacture of 24.4 million pcs. brick of concrete wall stones, that is in 1,5 times less than in previous year. But lighter and cheaper foam concrete blocks and gas-blocks displaced such a type of wall stone.

It was established that the effect of increasing the silicate bricks strength depends on the conditions of an active silica component adding in the quantity exceeding $1 \%$. It is also possible to reduce the active lime flow in the mix to 5-6 \% by weight, with a proportional increase in the amount of silicon dioxide added from zero to $6 \%$ by mix mas. It is known that the most silica-based material in the Zhytomyr region is granite and quartzite crushed waste.

As a result of calculations the following models of initial mix sintering parameters depending on the content of one of the components were obtained: sintering temperature $-1225{ }^{\circ} \mathrm{C}$, water absorption $-5,6 \%$, bending strength - 15,4 MPa, density gain - 0,8, shrinkage - 0,8 The mix components were: crushed granite waste of Volodarsko-Volynsky deposit and kaolinite product of Irshansk GZK factory.

L.Martynenko has established quality indicators of asphalt concrete mix on the basis of compact-grained sand of Smolivsky pit and crushed granite waste of Korostensky pit. The source materials quality is presented in table 4.

Table 4

Characteristics of the asphalt concrete mix components

\begin{tabular}{|c|c|c|c|c|c|c|c|c|c|c|}
\hline \multirow{2}{*}{$\begin{array}{l}\text { Mixtures } \\
\text { ingredients }\end{array}$} & \multicolumn{6}{|c|}{$\begin{array}{c}\text { Granulometric composition, \% } \\
\text { by factions, mm }\end{array}$} & \multirow{2}{*}{$\begin{array}{l}\text { Density, } \\
\mathrm{g} / \mathrm{sm}^{3}\end{array}$} & \multirow{2}{*}{$\begin{array}{l}\text { Bulk } \\
\text { mass, } \\
\mathrm{g} / \mathrm{sm}^{3}\end{array}$} & \multirow{2}{*}{$\begin{array}{l}\text { Sizing } \\
\text { module }\end{array}$} & \multirow{2}{*}{$\begin{array}{l}\text { Mass } \\
\text { fraction } \\
\text { in the } \\
\text { mixture }\end{array}$} \\
\hline & 2,5 & $\begin{array}{c}1,25- \\
2,5\end{array}$ & $\begin{array}{c}0,63- \\
1,25\end{array}$ & $\begin{array}{c}0,315- \\
0,63\end{array}$ & $\begin{array}{l}0,14- \\
0,315\end{array}$ & $<$ & & & & \\
\hline $\begin{array}{c}\text { Crushed-granite } \\
\text { waste of } \\
\text { Korostensky pit }\end{array}$ & 23,5 & 20,5 & 23,5 & 13,5 & 8,0 & 10,5 & 2,71 & 1,40 & 3,94 & 2,9 \\
\hline $\begin{array}{c}\text { Sand of } \\
\text { Smolivsky pit }\end{array}$ & 1,0 & 3,0 & 18,5 & 47,0 & 26,0 & 4,5 & 2,69 & 1,38 & 1,92 & 1,5 \\
\hline
\end{tabular}

Characteristics of concrete strength to a large extent depend from fillers water absorption. So, granite-based concrete, which is formed during the crushed stone production for the railways construction, is characterized by a higher water-cement ratio, and therefore - less durability compared with concrete, in which as a filler crushed granite waste of Korostensky pit was used. The most optimum was the mix consisting $65 \%$ of Korostensky crushed granite waste and $35 \%$ of the sands. Investigations of crushed granite waste frost resistance showed that concrete on its basis meets the requirements of the standard.

Crushed-granite waste is often used for production of various reinforced concrete products, and structural solution from crushed-granite waste and cement is very high-quality. The concrete, made on the basis of small granite dropout, is most demanded in landscape design. With this material, tiles are created for the sidewalk, different types of reservoirs, the territories, adjacent to the houses, flower beds and many other elements of decor are decorated. The main use of the crushed-granite waste is reduced to the full sand replacement or its using as a partial substitute.

In production, it is necessary to pay attention to all components and their quality. For production of highquality solution, the diameter of the applied clear crushed-granite waste should be 1,5-4 mm. Crushed-granite waste with more shallow particles are absolutely not suitable for the concrete manufacture. Special attention should be paid to quality of the used material, because crushed-granite waste should not contain any impurities.

To use crushed-granite waste in the structures construction, it needs to be prepared as appropriate. It preparation consists in washing from clay, dust and oozy particles, and also in the further large fractions fragmentation after sifting operation. The received sand in quality comes nearer to natural sand for construction work.

In production of a silicate bricks and other silicate products, natural sand can be replaced by some sandy kinds of waste. In particular, the waste of wet and dry enrichment of an ilmenite concentrate at the Irshansky 
GZK factory, introduced into a silicate mixture instead of the aggregate sand, provides increased raw material strength. Introduction of coarse-grained sand-filler from crushed-granite waste allows to increase the silicate products strength by $30 \%$.

According to the production organizations for 2012, the annual crushed-granite waste output on gravel pits is 4,5 million $\mathrm{m}^{3}$. It is estimated that from this dropout it is possible to produce not less than $3,5 \mathrm{million}^{3}$ of sand for construction and road works. But, today, crushed-granite waste is applied without enrichment and mainly as a material for the propagation of roads.

The crushed-granite waste cost at Zhytomyr crushed stone pits is $0,5-2 \$ / \mathrm{m}^{3}$. The realization cost of nonenriched crushed stone waste is $2-2,5 \$ / \mathrm{m}^{3}$, that is on the majority pits is close to prime cost. Whereas the washed sand price is about $4-5 \$ / \mathrm{m}^{3}$.

4. Environmental features of waste recycling.

Utilization of the industrial wastes is directed first of all to environmental protection and, only as a result, to production and receiving an economic benefit. In this regard, some have to be well understood, at first sight nonrational, actions of the production enterprises: sale of waste and products from them below cost, waste transfer to consumers it is free, waste delivery to consumers by the transport of waste producers, financing of researches on the environment, carrying out waste spaces recultivation, recovery of a fertile layer, etc.

The use of industrial wastes by the production of building materials, the creation of masonry and dams, the filling of waste pits requires the huge quantities of various wastes processing and transfer. The transition of such a mass of waste into the secondary mineral resources category contributes to the release of waste land, the air purification from gas and dust emissions, formed in dumps under the atmospheric agents influence, prevents the harmful substances removal from the dumps with surface waters, reduces the river waters pollution extent.

Ultimately, comprehensive work is being undertaken to preserve and restore natural landscapes, to improve the human habitat's environment. Proceeding from this, the environmental priorities of industrial waste utilization are determined, economic and environmental efficiency is estimated, practical tasks for waste utilization in the national economy are developed.

In Zhytomyr region, the priorities settle down in the following order:

- conducting research and experimental works with studying of opportunities of the fullest and versatile recovery of the mining industry, utilization of these wastes, wastewater regeneration, and the dumping of harmful impurities. It is important to prevent the entry of these harmful to humans, animals and vegetation of materials in surface and underground waters, which will allow them to significantly clean them from impurities and bring them closer to the natural waters in chemical composition;

- holding of design and organizational actions for the achievement of low-level technologies for the crushed stone waste processing of mining and extraction complex enterprises. It is necessary to critically evaluate the efficiency and feasibility of technological processes practical use and production schemes of building materials developed by experts.

In November 2017, the Government of Ukraine adopted a National Waste Management Strategy. The strategy is a comprehensive document until 2030 and is based on three key principles of the European Union, namely:

1. The transition to a closed loop economy, which is basis of sustainable development strategy. For Ukraine, this means large-scale technological modernization and the abandonment of consumer attitude to natural resources.

2. Increased producer liability which will encourage businesses to minimize waste generation and interest in their recycling.

3. The third main principle of the Strategy is the introduction of a five-level hierarchy of waste management, which operates in the European Union. Its priority is to prevent the generation of waste and the least acceptable option is disposal.

Thus, environmental priorities are intimately bound to the economy of mining and industrial products production, contribute to stabilization and further improvement of natural landscapes and human habitat.

Conclusions. The relevance of a problem of mineral resources complex use admits both by scientists and industry now. In this regard, industrial waste status assessment of the Zhytomyr region, the analysis of degree and the nature of their utilization, development of proposals for the rational use of natural (minerals) and secondary (industrial waste) mineral resources can determine the long-term policy to expand the construction materials production in the region both on the basis of natural raw materials and with the use of waste. Utilization of the last has an important environmental significance, as it promotes the dumps elimination, reducing the amount of harmful impurities in the atmosphere and water, releasing lands for cultural, agricultural, urban development and other purposes.

The bulk of the generated and accumulated industrial waste is anthropogenic building material, the use of which will allow to limit the depletion of the subsoil, to improve an ecological state, to increase production of construction products, to return a part of arable lands to agriculture. 
Thus, the possible uses of crushed stone waste are as follows: cement manufacturing, filler material in tiles and brick-wall stones making, lime manufacture, wall coatings in buildings, filler in concrete and asphalt concrete, geopolymer binder, paving material.

Prospects of further research. The industrial wastes are characterized by a composition and properties variety and a wide range of uses, therefore, it is advisable to create an information database on existing and newly formed waste, which will determine the secondary raw materials cost, requirements for preservation and recycling for optimal solution of the rational nature management tasks.

\section{Список використаної літератури:}

1. Губанова E.P. Механизм экономико-экологического стимулирования использования вторичных ресурсов : монография / E.P. Губанова. - Одесса : Одесский государственный экологический университет, $2009 .-280$ с.

2. Давидова I.B. Оцінка фізико-хімічних властивостей лісових грунтів у зоні техногенного впливу щебеневих кар'єрів на Житомирському Поліссі / I.B. Давидова // Агроекологічний журнал. Спеціальний випуск. - 2010. C. 74-81.

3. Коробійчук B.B. Геометризація супутньої корисної копалини в умовах Лезниківського родовища гранітів та гірничо-геометричний аналіз його показників / B.B. Коробійчук, О.О. Кісєль, В.A. Стріха // Вісник Національного університету водного господарства та природокористування. Серія : Технічні науки. - 2012. № 2 (58). - С. 175-184.

4. Багазеев В.К. Определение интенсивности уноса мелких частиц воздушным потоком с поверхности отвалов / В.К. Багазеев, Н.Г. Валиев // Изв. вузов. Горный журнал. - 1994. - № 4. - С. 69-72.

5. Лапшин A.E. Сокращение распространения пыли в атмосфере при складировании горной массы на открытых складах / A.E. Лапшин // Изв. вузов. Горный журнал. - 1994. - № 8. - С. $62-66$.

6. Прокопенко В.И. Исследование путей снижения интенсивности загрязнения природы горно-обогатительным производством / В.И Прокопенко // Изв. вузов. Горный журнал. - 1997. - № 1-2. - С. 14-17.

7. Лычагин E.B. Совершенствование методов закрепления пылящих поверхностей / E.B. Лычагин, И.B. Синица // Горный информационно-аналитический бюллетень. - 2007. - № 8. - С. 136-140.

8. Мальшев Ю.Н. Физико-химические процессы при добыче полезных ископаемых и их влияние на состояние окружающей среды / Ю.Н. Мальщев, А.Т. Айруни, Е.Ю. Куликова. - М. : Академия горных наук, $2002 .-270$ с.

9. Incorporation of granite waste in red ceramics / C.M.F. Vieira, T.M. Soares, R.Sánchez, S.N. Monteiro // Materials Science and Engineering. - 2004. - No. 373. - Pp. 115-121. - Access mode : https://doi.org/10.1016/j.msea.2003.12.038.

10. Hojamberdiev M. Utilization of muscovite granite waste in the manufacture of ceramic tiles / M.Hojamberdiev, A.Eminov, X.Yunhua // Ceramics International. - 2011. - Vol. 37, Issue 3. - Pp. 871-876. - Access mode : https://doi.org/10.1016/j.ceramint.2010.10.032.

11. Dust formation and use of rocks dust at industrial sites / S.Ya. Davydov, N.G. Valiev, N.M. Suslov, A.N. Semin, A.I. Ermolaev, T.N. Cheremisina, M.S. Filatov // News of the Ural State Mining University. - 2016. - No. 3 (43). Pp. 87-90. - Access mode : https://doi.org/10.21440/2307-2091-2016-3-87-90.

12. Experimental investigation of the utilization of quarry dust for the production of microcement-based building elements by self-flowing molding casting / M.Galetakis, Ch.Piperidi, A.Vasiliou, G.Alevizos, E.Steiakakis, K.Komnitsas, A.Soultana // Construction and Building Materials. - 2016. - Vol. 107. - Pp. 247-254. - Access mode : https://doi.org/10.1016/j.conbuildmat.2016.01.014.

13. High-performance concrete with recycled stone slurry / N.Almeida, F.Branco, J.Brito, J.R. Santos // Cement and Concrete Research. - 2007. - Vol. 37 (2). - Pp. 210-220. - Access mode : http://doi.org/10.1016/j.cemconres.2006.11.003.

14. Eroshkina N. The Effect of the Mixture Composition and Curing Conditions on the Properties of the Geopolymer Binder Based on Dust Crushing of the Granite / N.Eroshkina, M.Korovkin // Procedia Engineering. - 2016. - Vol. 150. Pp. 1605-1609. - Access mode : https://doi.org/10.1016/j.proeng.2016.07.137.

15. Potential of using granite waste as raw material for geopolymer synthesis / L.N. Tchadjié, J.N.Y. Djobo, N.Ranjbar, H.K. Tchakouté, B.B.D. Kenne, A.Elimbi, D.Njopwouo // Ceramics International. - 2016. - Vol. 42, Issue 2. Pp. 3046-3055. - Access mode : https://doi.org/10.1016/j.ceramint.2015.10.091.

16. European Commission. EU Construction \& Demolition Waste Management Protocol. - 2016. - Access mode : http://ec.europa.eu/growth/content/eu-construction-and-demolition-waste-protocol-0_en.

\section{References:}

1. Gubanov, E.R. (2009), Mekhanizm ekonomiko-ekologicheskogo stimulirovaniia ispolzovaniia vtorichnykh resursov, monografiya, Odesskiy gosudarstvennyy ekologicheskiy universitet, Odessa, $280 \mathrm{p}$.

2. Davy`dova, I.V. (2010), «Otsinka fizyko-khimichnykh vlastyvostei lisovykh gruntiv u zoni tekhnohennoho vplyvu shchebenevykh karieriv na Zhytomyrskomu Polissi», Agroekologichnyj zhurnal. Special'nyj issue, pp. 74-81.

3. Korobiichuk, V.V., Kisyel, A.A. and Strikha, V.A. (2012), «Heometryzatsiia suputnoi korysnoi kopalyny v umovakh Leznykivskoho rodovyshcha hranitiv ta hirnycho-heometrychnyi analiz yoho pokaznykiv», Proceedings of the National University of Water and Environment, Serija Tehnichni nauky, No. 2 (58), pp. 175-184.

4. Bagazeev, V.K. and Valiev, N.G. (1994), «Opredelenie intensivnosti unosa melkih chastic vozdushnym potokom s poverhnosti otvalov», Izv. vuzov. Gornyj zhurnal, No. 4, pp. 69-72. 
5. Lapshin, A.E. (1994), «Sokrashhenie rasprostranenija pyli v atmosfere pri skladirovanii gornoj massy na otkrytyh skladah», Izv. vuzov. Gornyj zhurnal, No. 8, pp. 62-66.

6. Prokopenko, V.I. (1997), «Issledovanie putej snizhenija intensivnosti zagrjaznenija prirody gorno-obogatitel'nym proizvodstvom», Izv. vuzov. Gornyj zhurnal, No. 1-2, pp. 14-17.

7. Lychagin, E.V. and Sinica, I.V. (2007), «Sovershenstvovanie metodov zakreplenija pyljashhih poverhnostej», Gornyj informacionno-analiticheskij bjulleten', No. 8, pp. 136-140.

8. Malyshev, Ju.N., Ajruni, A.T. and Kulikova, E.Ju. (2002), Fiziko-himicheskie processy pri dobyche poleznyh iskopaemyh i ih vlijanie na sostojanie okruzhajushhej sredy, Akademija gornyh nauk, M., 270 p.

9. Vieira, C.M.F., Soares, T.M., Sánchez, R. and Monteiro, S.N. (2004), «Incorporation of granite waste in red ceramics», Materials Science and Engineering, No. 373, pp. 115-121, available at: https://doi.org/10.1016/j.msea.2003.12.038

10. Hojamberdiev, M., Eminov, A. and Yunhua, X. (2011), «Utilization of muscovite granite waste in the manufacture of ceramic tiles», Ceramics International, Vol. 37, Issue 3, pp. 871-876, available at: https://doi.org/10.1016/j.ceramint.2010.10.032

11. Davydov, S.Ya., Valiev, N.G., Suslov, N.M., Semin, A.N., Ermolaev, A.I., Cheremisina, T.N. and Filatov, M.S. (2016), «Dust formation and use of rocks dust at industrial sites», News of the Ural State Mining University, No. 3 (43), pp. 87-90, available at: https://doi.org/10.21440/2307-2091-2016-3-87-90

12. Galetakis, M., Piperidi, Ch., Vasiliou, A., Alevizos, G., Steiakakis, E., Komnitsas, K. and Soultana, A. (2016), «Experimental investigation of the utilization of quarry dust for the production of microcement-based building elements by self-flowing molding casting», Construction and Building Materials, Vol. 107, pp. 247-254, available at: https://doi.org/10.1016/j.conbuildmat.2016.01.014

13. Almeida, N., Branco, F., Brito, J. and Santos, J.R. (2007), «High-performance concrete with recycled stone slurry», Cement and Concrete Research, Vol. 37 (2), pp. 210-220, available at: http://doi.org/10.1016/j.cemconres.2006.11.003

14. Eroshkina, N. and Korovkin, M. (2016), «The Effect of the Mixture Composition and Curing Conditions on the Properties of the Geopolymer Binder Based on Dust Crushing of the Granite», Procedia Engineering, Vol. 150, pp. 1605-1609, available at: https://doi.org/10.1016/j.proeng.2016.07.137

15. Tchadjié, L.N., Djobo, J.N.Y., Ranjbar, N., Tchakouté, H.K., Kenne, B.B.D., Elimbi, A. and Njopwouo, D. (2016), «Potential of using granite waste as raw material for geopolymer synthesis», Ceramics International, Vol. 42, Issue 2, pp. 3046-3055, available at: https://doi.org/10.1016/j.ceramint.2015.10.091

16. «European Commission. EU Construction \& Demolition Waste Management Protocol» (2016), available at: $\mathrm{http} / / /$ ec.europa.eu/growth/content/eu-construction-and-demolition-waste-protocol-0_en

Levytskyi Volodymyr Hryhorovych - Ph.D., Associate Professor of Mine Surveying Department of Zhytomyr State Technological University.

Scientific interests:

- mining;

- mine surveying;

- photogrammetry;

- construction materials.

Tolkach Oleksandr Mykolaiovych - Ph.D., Associate Professor of Deposits Development Department named after M.T. Bakka, Zhytomyr State Technological University.

Scientific interests:

- mining;

- construction materials;

- computer technologies.

The article was sent to the publishing department on 20.11.2017. 